\title{
Challenges for recovery of large carnivores in humanized countries: attitudes and knowledge of sheep farmers towards brown bear in Western Pyrenees, Spain
}

\author{
Juan Herrero ${ }^{1}$ · $\cdot$ Alicia García-Serrano ${ }^{2} \cdot$ Ramón Reiné $^{1} \cdot$ Vicente Ferrer $^{3} \cdot$ Ricardo Azón $^{4} \cdot$ José Vicente López-Bao ${ }^{5}$. \\ Guillermo Palomero ${ }^{6}$
}

Received: 28 February 2021 / Revised: 1 November 2021 / Accepted: 7 November 2021 / Published online: 22 November 2021

(c) The Author(s) 2021

\begin{abstract}
During 2017, we studied knowledge, perceptions, and attitudes towards brown bears by extensive mountain sheep farmers in the Western Pyrenees, using a structured questionnaire, specifically, whether the scarce bear presence, or the administrative region, was influential. Livestock raising practices are mainly family properties and have suffered a strong decline in the last decades. Despite its low abundance (only 2 bear individuals during the study period in the area), there was a generalized negative attitude towards the presence of bears. Farmers considered bear presence as incompatible with sheep mountain herding. One third of them have experienced bear damages, although this was not the main difficulty for the viability of farming practices. They were able to change husbandry practices after wildlife and dog's damages, increasing vigilance, hiring shepherds, and using livestock guarding dogs, whose work is perceived as satisfactory. Farmers considered that information available about bear and compensation systems for damages was insufficient, and should be improved.
\end{abstract}

Keywords Sheep farmers $\cdot$ Damages $\cdot$ Mountain range $\cdot$ Attitude $\cdot$ Perception $\cdot$ Knowledge

\section{Introduction}

After a long period of persecution, brown bear Ursus arctos populations are slowly recovering across several European countries (Chapron et al. 2014; Piédallu et al. 2016a). The recovery of bears, as many other large carnivore populations, is not exempt from negative impacts between these species and humans, and the emergence of multiple conflicts among humans on how to conserve and manage these species (Treves and Bruskotter 2014; López-Bao et al. 2017).

Juan Herrero

herreroj@unizar.es

1 Department of Agrarian and Environmental Science, University of Zaragoza, Huesca, Spain

2 Ega Wildlife Consultants, Zaragoza, Spain

3 Belardi Consultants, Burlada, Navarra, Spain

4 Farmer and Consultant, Orós Bajo, Huesca, Spain

5 Research Unit in Biodiversity (UO/CSIC/PA), University of Oviedo, Mieres, Spain

6 Fundación Oso Pardo / Brown Bear Foundation, Santander, Spain
Complete absence, or the persistence of a very few number of individuals, over several human generations results in societies that have lost important adaptations contributing to facilitate the coexistence with large carnivores, or just the willingness to share the landscape with them (López-Bao et al. 2017). As a result, intolerance, fear, or resentment can emerge when they return.

In most cases of coexistence between humans and large carnivores, some level of negative interactions can be expected (Chapron and López-Bao 2016; López-Bao et al. 2017). In Europe, attitudes towards brown bears have been described as more positive compared to other large carnivores, such as grey wolf Canis lupus (Dressel et al. 2014). Bear presence and recovery in multi-used landscapes can have some negative impacts, and associated level of conflicts, either because of livestock, beehives or crop damages (e.g., Bautista et al. 2017; Naves et al. 2018), attacks on humans and fear (Johansson et al. 2012; Bombieri et al. 2018), or conflicts driven by different human land uses and regulations, such as in the case of balancing ecotourism activities with bear conservation (Planella et al. 2019). All these factors could influence on attitudes towards the 
presence of the species, and support for their conservation (e.g., Johansson et al. 2012; Kansky and Knight 2014).

Brown bears have been traditionally present across the Pyrenees. In the middle of the nineteenth century, Madoz (1846) listed the municipalities in the Spanish Pyrenees where brown bears occurred, showing that the species was mentioned throughout the entire area. However, this population progressively declined since (Chapron et al. 2014). This decline has been more important, and occurred earlier, in the Spanish slope of this mountainous range. In 2017, the presence of bears in the whole Western Pyrenees was residual, with just a couple of males (Palazón et al. 2013, 2017). In a context of bear recovery in the Pyrenees (Palazón 2017), the return of bears in areas where the species has almost disappeared, or has been absent for decades, may be perceived negatively because of their potential impact on some grazing activities that have lost the co-adaptation to coexist with this species in remote mountainous areas (Carter and Linnell 2016; López-Bao et al. 2017) such as, for example, the presence of unguarded livestock flocks and the abandonment of livestock damage preventions measures (Eklund et al. 2017). Grazing activities are important for the maintenance of grasslands protected by the European conservation regulation (i.e., habitats listed under the 92/43/ EEC Habitats Directive; AA. VV 2009, see below). These pastures are the mountain ranges used by livestock.

Livestock husbandry practices have evolved in the last decades in a context in which the large carnivores in the Pyrenees were almost absent. As a consequence, the recovery of large carnivores, such as brown bears and wolves, here implies adapting livestock practices to a non-predator free landscapes again (Chapron et al. 2014; Carter and Linnell 2016; López-Bao et al. 2017). In the Pyrenees, brown bear attacks to sheep Ovis aries are perceived as the main negative impact of bear presence, and an important threat to farm viability (Caussimont and Herrero 1997). Livestock depredation has probably driven the historical regression of the species in these mountains through direct persecution, and may be the main factor opposing the recovery of bears nowadays. Several initiatives have been implemented in the Pyrenees with the aim of promoting shared landscapes between bears and livestock activities, stimulating changes in livestock husbandry practices, as gathering together flocks, contracting shepherds, use of electric fences, use of livestock guarding dogs, among others (Palazón et al. 2018).

In recent years, human dimensions have been explored across different bear populations in Europe, from large to small, or from recovering to reintroduced populations (e.g., Majić et al. 2011; Dressel et al. 2014; Glikman et al. 2019; Piédallu et al. 2016b, 2019; Hovardas 2018). Still, there is a lack of information in those scenarios where the size of remnant large carnivore populations is very small and close to extirpation, such as the case of bears in the
Western Pyrenees. Understanding human dimensions at different stages of the large carnivore recovery process is crucial, for example, before large carnivore reintroductions (Sakurai et al. 2020; Williams et al. 2002) or when the species has been recovering for some time (Glikman et al. 2019; Piédallu et al. 2019) perhaps triggered by an increase in conflicts. In this regard, understanding human dimensions when a population is almost extinct may contribute to advance our knowledge on those factors contributing to the loss of co-adaptation processes and triggering opposition when they return. In this study, we were interested in evaluating attitudes and knowledge in relation to bear presence when the species is almost gone (two individuals in the entire study area). This research was undertaken before a new reinforcement of brown bear population in the French Pyrenees neighboring the study area during 2018 ( 2 females). Therefore, we were also interested in knowing the state of the sheep farms in areas of future expansion for bears in the Western Pyrenees. In particular, we focused on extensive sheep farmers that take their flocks to the mountain pastures during summer. We explored farmer's attitudes towards bears in two areas, one with the two remnant male bears at the time of the study, and a surrounding area without confirmed attacks on livestock or presence of the species in recent times. Based on our findings, we propose proactive measures to reconcile extensive livestock husbandry practices in these mountains and the recovery of the brown bear in the Pyrenees.

\section{Study area}

The study area comprises the mountain summer ranges located in Southwestern Pyrenees valleys in the regions of Aragon (Jacetania district) and Navarre (Valleys of Roncal and Salazar) (Spain) (Fig. 1). The fundamental economic activity in this region is tourism, followed by livestock husbandry practices, with agriculture and forestry being a minority. Pastures are located above the upper level of the forest, in communal mountain ranges, and sheep graze in these pastures mainly during summer a total fifty-nine communal mountain ranges, occupying 22,690 ha (Fillat Estaqué et al. 2007; Ferrer and Canals 2011). The area overlaps with several Special Areas of Conservation and Special Protection Areas for birds, with the Natural Reserve of Larra-Belagoa and the Natural Park of the Western valleys. These pastures are included in the High Natural Value farmlands within the Common Agricultural Policy, and listed in the 92/43/EEC Habitats Directive. Their management plans include extensive grazing as the main activity for its conservation (AA. VV. 2009).

In $2017,57,682$ sheep heads, belonging to five native breeds (Rasa, Latxa, Xisqueta, Churra-Tensina and 


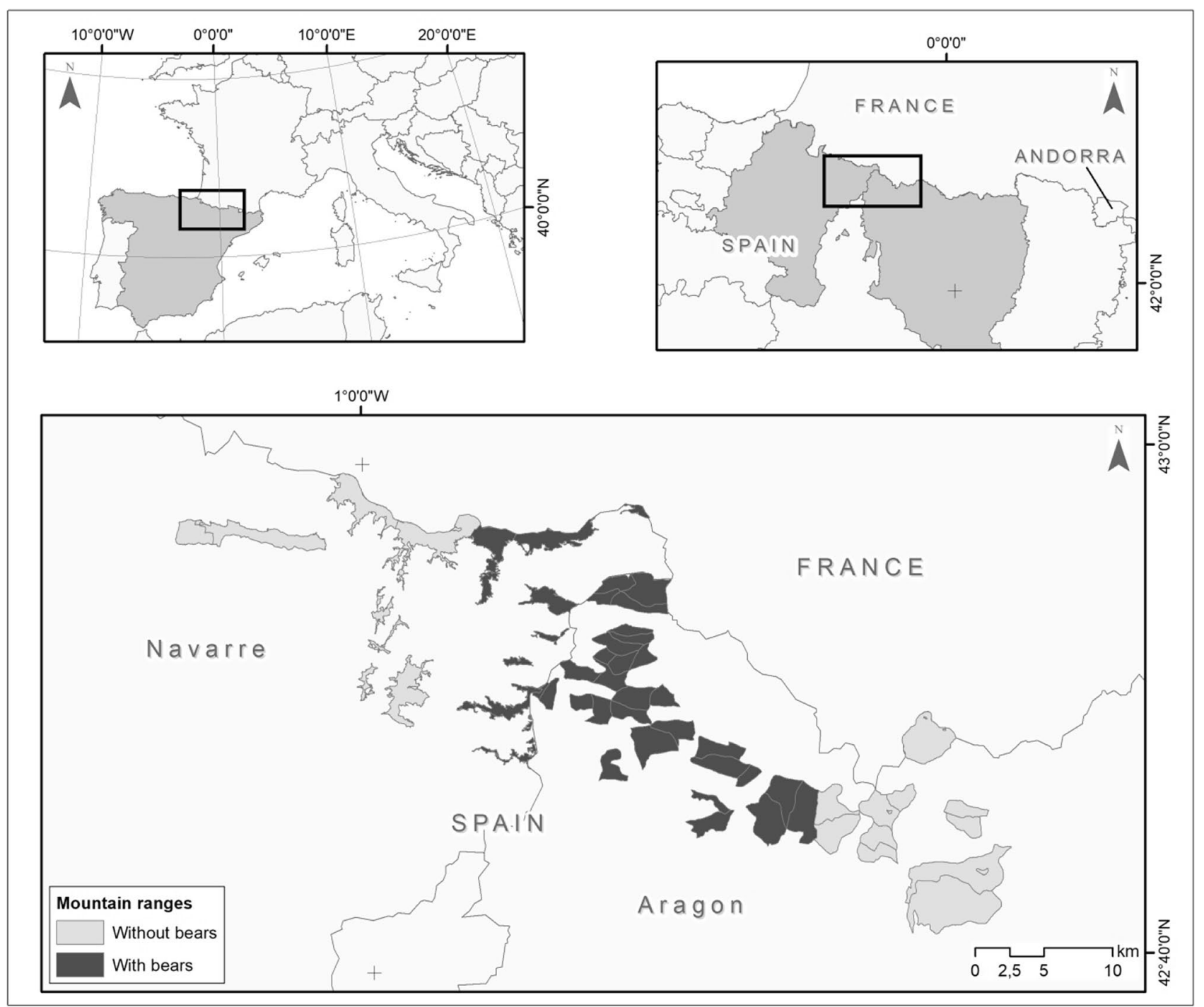

Fig. 1 Study area

Ansotana) - the last three endangered (MAPA 2019) spent the summer grazing in these mountain ranges. Infrastructures available there for livestock practices are access paths, water troughs, huts, and sheep handling systems. During the last decades, there has been an important decrease in the number of extensive sheep and goat Capra hircus farms. In Jacetania, between 1995 and 2015 when bears where already declining and in few numbers in the area (Palazón et al. 2013), the decrease was from 485 to 263 farms $(-47 \%)$, and from 94,224 to 82,435 sheep $(-11 \%)$ (Roldán 2016), indicating an intensification of the extensive livestock sector, drove by the Common Agricultural Policy (Navarro and López-Bao 2018), in order to maintain farm profitability. In Navarre (Roncal Valley), on the other hand, a reduction of $34 \%$ in the number of sheep heads who use mountainous summer ranges was observed between 2005 and 2014 (Mangado 2016). The strong decline observed in the livestock sector in the last decades, together with a rural abandonment process (Urzainki 1980; Villar and Lorda, 1992; Ferrer and Canals, 2011; Mangado 2016), has led to an increase in the area occupied by forests (Gastón Romeo and de la Riva Fernández 2015).

During the study period, there was a different compensation system implemented associated to bear damages in each region. In addition, farmers were subsidized also for potential nuisances. The average time to receive compensation by farmers was 2-3 months in Aragon. However, since 2015, the time from when a bear attack was reported and the farmers received compensation lasted till 2-3 years. In Navarre, the reception of compensations is regularly before the end of the fiscal year, exceptionally in one case it took one year. During the study period, there were no subsidies allocated 
by the authority of Aragon to implement damage prevention measures. No active measures had even taken place in the past, such as shepherd contracts, electric fences, mountain huts refurbishment, watering troughs construction, and guard dogs purchase. In Navarre, active prevention measures were in place, however, with additional personnel dedicated to herd vigilance during the night.

\section{Material and methods}

Our goal was to survey those farmers in southwestern Pyrenees that take their sheep to the summer mountain pastures. We interviewed 58 farmers, 32 in Navarre and 26 in Aragon, which represents about $65 \%$ of the farmers that use these pastures (official data and our own data).

Farmers were sampled using a structured questionnaire with the following sections: (i) general characteristics of the farm; (ii) livestock husbandry practices in summer ranges; (iii) interaction with wildlife; (iv) bears (knowledge of the existence of bears in the mountain ranges they use, perception, attitude, and degree of agreement before this presence). The types of questions used were mixed, from binary and single-multiple options to Likert scale questions (Likert 1932; Heiberger and Robbins 2014; Heiberger 2020). We previously tested the questionnaire with 2 volunteers (not included in the sample), in order to avoid possible imperfections that could invalidate the information obtained. Personal interviews were carried out by two experienced interviewers and coauthors (Ricardo Azón, farmer and Vicente Ferrer, consultant in pastures and extensive farming) after requesting an appointment with the farmer. We carried out the interviews between March and May 2017. We duly informed each farmer before the interview, on the objective of the survey, its importance, who carried it out as well as that the results could not be related to him or her since the personal references were eliminated from the generated databases to comply with the General Data Protection Regulation (EU) 2016/679 (GDPR). All interviewees agreed to allow us to use the information from their interviews in subsequent analyses.

First, we undertook a descriptive analysis of each topic. For each item, we show the total sample size, after eliminating those interviews that did not contain information on each particular item (i.e., sample size will vary across the results). Secondly, to identify factors that affect farmer's attitudes, we conducted an ordinal logistic regression analysis of proportional odds model, where the logit compares lower or equal vs higher response probabilities (Heiberger and Robbins, 2014), performed with the SPSS PLUM procedure. We fitted this cumulative link model by maximum likelihood and we used a negative log-log link function, recommended when the probability of the lower category is high. Possible explanatory variables of the different response variables were the variable "Presence of bear" in the mountain pastures where sheep farmers carry their flocks during the summer and "Region" where the mountain pastures are located, Aragon and Navarre (due to different management strategies implemented). Considered models were those in which the introduced variables significantly improve the fit, the models fit the data adequately and meet the condition of proportional odds, verified with the parallel line test.

\section{Results}

\section{Description of the extensive sheep farming activity in the study area}

Farms belonged mainly to families ( $95 \%, n=58)$, with single or couple owner properties $(91 \% ; n=57$; for those interviews with data we observed that around $6 \%$ of the owners were women, $n=53$ ). The average owner's age was 50.2 years $(\mathrm{SD}=10.6,95 \%$ CIs [47.3, 53.2], $n=52)$. Almost all farmers $(98 \%, n=57)$ are full time. Nearly three quarters of farms $(74 \%, n=58)$ are inherited, and only two farms were of recent creation (less than 10 years old). Most of the farms only employ one person $(71 \% ; n=56)$, which is the owner himself, and only in $13 \%$ of the farms there were two family members employed (only five of the 58 farms usually had one or two employees). The average size of the herds was 966 sheep heads ( $\mathrm{SD}=850.5,95 \%$ CIs [742, 1.189], $n=58$ ), mostly for meat production. Forty-seven percent $(n=55)$ of the farms hold the European qualification of protected designation of origin, and a protected geographical indication, in some of their products. Forty-five percent of farmers $(n=58)$ were from Aragon, and 55\% from Navarre.

The majority of farmers $(60 \%, n=58)$ considered that the profitability of the farm has decreased in the last 5 years (38\% believed that it has remained constant, and only one considered that it has increased; i.e., the only young farmer with a newly created farm of less than 10 years). From the perspective of the farmers, the three main factors of such decrease in profitability were (i) the low market value of meat (lambs), (ii) the increment in production costs (i.e., food for livestock during winter times, fuel, or the lease of pastures), and (iii) the decrease in the aids and subsidies on which this activity currently depends on.

\section{Livestock husbandry practices in summer pastures}

On average, farmers kept their livestock in mountain ranges for 4 months ( $\mathrm{SD}=1.4,95 \%$ CIs [3.6, 4.3], $n=58$ ), mainly from June to September. Sixty-two percent $(n=58)$ of them were non-transhumant and had their farms in the valley bottoms, at a distance of less than a day walk. For transhumant 
Your general attitude towards the bear is

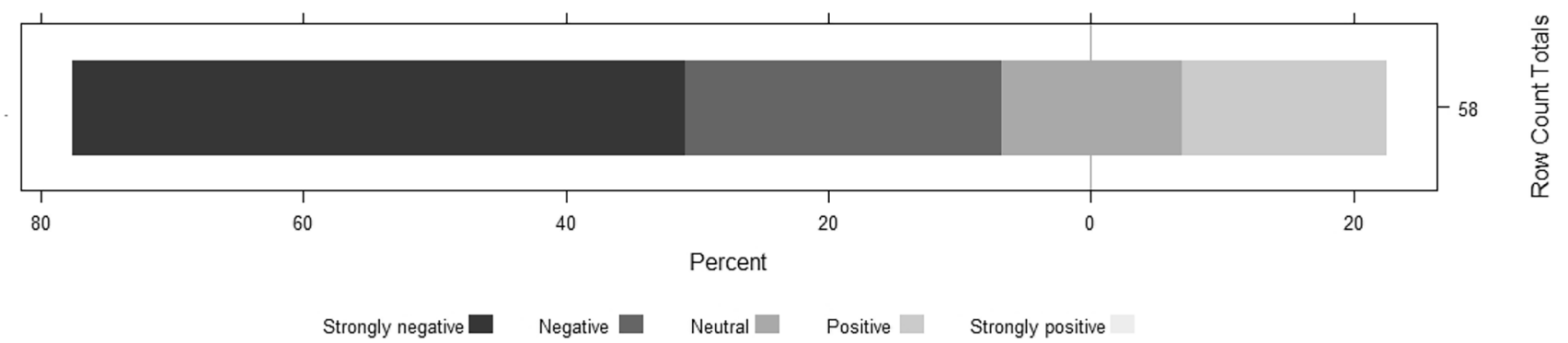

Fig. 2 Distribution of responses on general attitudes towards bear presence (Q2)

farmers (38\%), their farms were at an average of 7 days of walk. During summer, sheep remained continuously at the open mountain pastures, with no grazing limitation, and most of the time without any herd guidance. In fact, most farmers did not control their herds in summer pastures on a daily basis (56\%). Those farmers visiting their flocks on a daily basis (44\%) spent, on average, $11 \mathrm{~h}$ (SD $=6.1,95 \%$ CIs $[8.3,13.3]$, $n=26$ ). Remarkably, $12 \%$ did control their flocks only for veterinary compulsory treatments. During nights, only $22 \%$ of farmers $(n=58)$ kept their herds in sheepfolds, the majority of them due to forest regulations in Navarra aimed to preserve pastures. To handle herds, $78 \%$ of farmers $(n=55)$ used dogs (an average of $2.8 \mathrm{dogs}, \mathrm{SD}=1.5,95 \%$ CIs [2.4, 3.3], $n=43$ ), with most of them being (61\%) using shepherd dogs alone (30\% of farmers used shepherd and guard dogs, and $9 \%$ only guard dogs). In addition, $27 \%$ of farmers $(n=56)$ used GPS on their sheep (usually one per herd). Sixty-three percent $(n=32)$ of farmers from Navarre, and $24 \%(n=25)$ from Aragon, considered that available infrastructures in summer pastures (i.e., access tracks, watering places, handling facilities, shepherd huts, water basins, corrals and birthing sites) were sufficient to develop their activity there.

\section{Damage prevention measures}

Sixty percent of farmers $(n=58)$ adopted damage prevention measures in the mountain ranges. The most common were the used of guarding $\operatorname{dogs}(31 \%, n=55)$, followed by herders (always or usually, normally only one, $26 \%, \mathrm{n}=58$ ), and keeping herds in fenced enclosures during night hours $(22 \%$, $n=58$ ). The main justification to not implement damage prevention measures was the low number of damages produced by wildlife on the sheep flocks, as to spend their time and money in investing and implementing prevention measures $(40 \%, n=58)$. To a lesser extent $(5 \%)$, some farmers also believed that the implementation of these measures was not feasible in the mountain ranges. Importantly, all farmers interviewed considered that it is their own responsibility to adopt actions to protect their herds. Sixty-one percent $(n=59)$ of farmers were not aware of the existence of subsidies from authorities to promote bear damage prevention.

\section{Negative interactions with dogs and wildlife in summer pastures}

Almost all the farmers $(90 \%, n=58)$ declared that sheep herds had some type of conflicts with other animals, mainly dogs $(71 \%)$. In relation to wildlife, $71 \%$ of farmers declared to have suffered livestock damages during their professional career, with griffon vultures Gyps fulvus being the species more frequently mentioned (55\%), followed by brown bears (26\%), red fox Vulpes vulpes (14\%), raven Corvus corone (9\%), wild boar Sus scrofa (2\%) and wolf Canis lupus (2\%, one farmer in 1996). Overall, the 19 sheep breeders who suffered bear attacks reported that damages were mainly dead ewes and wounded animals, such as broken legs.

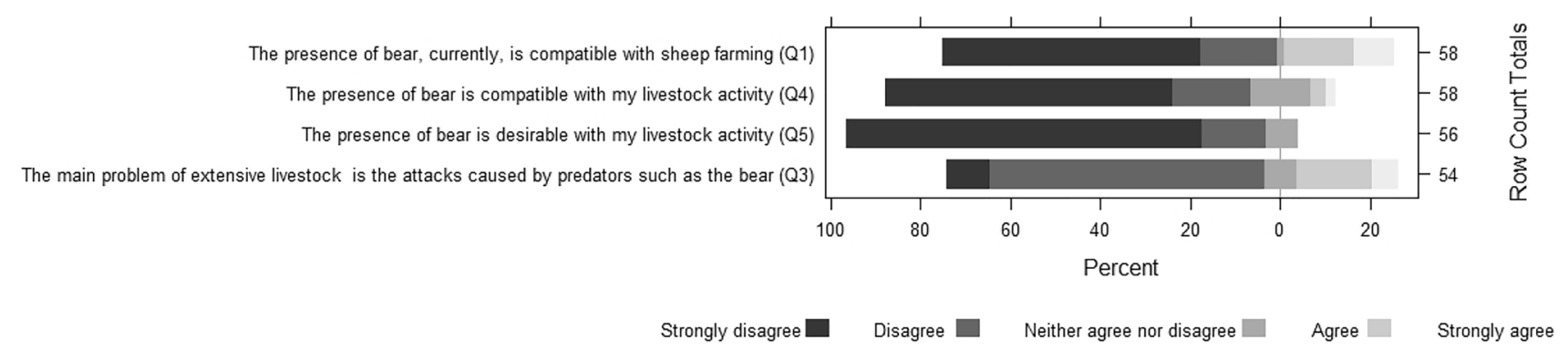

Fig. 3 Distribution of responses on the compatibility between livestock activities and the presence of bears 
The main problem of extensive livestock is the attacks caused by predators such as the bear

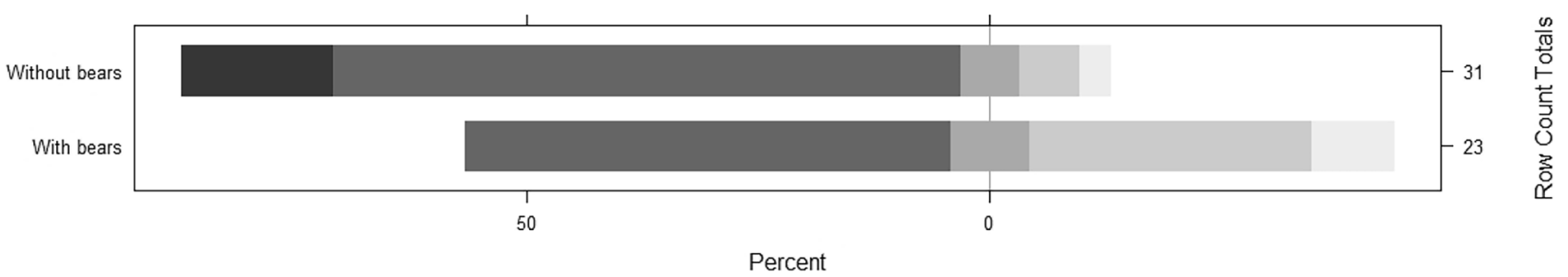

Strongly disagree $\square \quad$ Disagree $\square \quad$ Neither agree nor disagree $\square \quad$ Agree $\square \quad$ Strongly agree

Fig. 4 Distribution of responses on attacks by predators as the main problem of extensive livestock

Additionally, some farmers described abortions after the attack, alteration, and dispersal of herds, which could end in animal precipitation down cliffs and loss.

Fifty-seven percent of farmers had an insurance covering livestock damages (in $65 \%$ of cases the insurance covered all wildlife, in $15 \%$ of cases just dog damages, and in $20 \%$ of cases the farmer did not remember what species covered their insurance). Generally, farmers informed authorities about their last livestock damage $(84 \%, n=44)$ and $60 \%$ of them were compensated by the regional administrations or the insurance companies. The average period between the livestock attack and the compensation payment reported by farmers was 6.5 months ( $\mathrm{SD}=3.9,95 \%$ CI $[2.4,3.3]$, $n=22$ ). Among them, only $36 \%$ were satisfied with the amount compensated, and farmers also complained about the compensation process in terms of delays and mistrust.

\section{Bear presence}

Overall, $59 \%$ of farmers $(n=58)$ carried out their livestock activities in mountain ranges located in the peripheral zone of the bear area, compared to $41 \%$ of farmers developing their activities within the bear range. There were no differences in age between those farmers within and outside the bear area $(\mathrm{t}(50)=0.28, p=0.78)$, and between autonomous regions $(\mathrm{t}(50)=-1.68, p=0.01)$. The same pattern was observed in relation to the number of sheep heads (bear area: $\mathrm{t}(56)=0.55, p=0.58$, regions: $\mathrm{t}(56)=-0.48, p=0.63)$.

\section{Attitude towards the bear}

The majority of farmers showed a negative attitude towards bears (71\%, $n=58$; Table $1 \mathrm{Q} 2$ and Fig. 2). We did not find significant variation in attitudes towards bears in relation to carrying out the livestock activities within the bear area, or not, or the autonomous region.

\section{Livestock activity and presence of bear}

The majority of farmers did not consider bear presence compatible with livestock activity $(74 \%, n=58)$. This opposition increased to $81 \%(n=58)$ considered the compatibility referred to "their" own livestock activity (Fig. 3 and Table 1 Q4), and none that considered it was a desirable situation ( $n=56$, Fig. 3 and Table 1 Q5).

Contrary to the previous opinions, in general, most farmers did not consider that damages caused by predators such as the bear was the main problem for extensive livestock farming (70\%; $n=54$; Fig. 3 and Table 1 Q3). However, a different opinion emerged when separating farmers taking sheep to summer ranges with or without bear (Fig. 4 and Table 2 Q3). The probability of

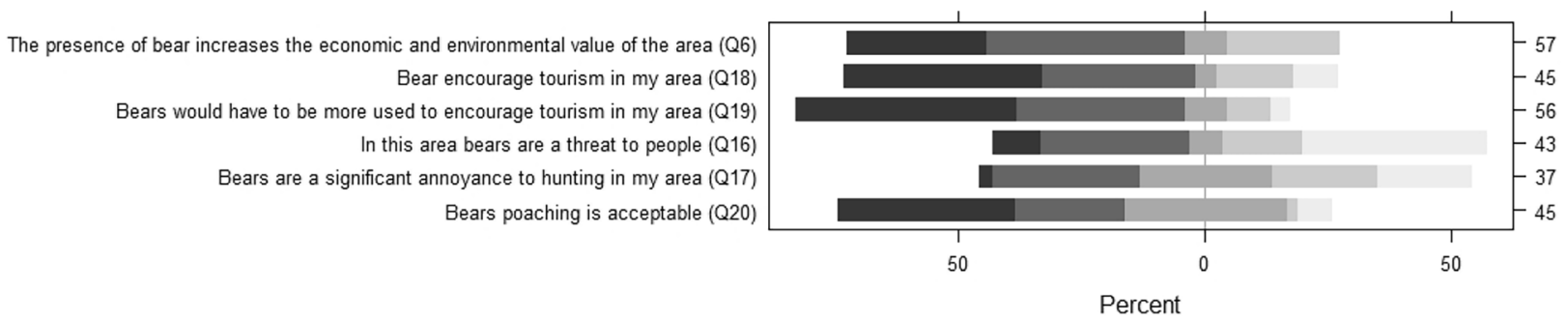

Fig. 5 Distribution of responses on tourism and hunting activities and the presence of bears 
The presence of bear increases the economic and environmental value of the area

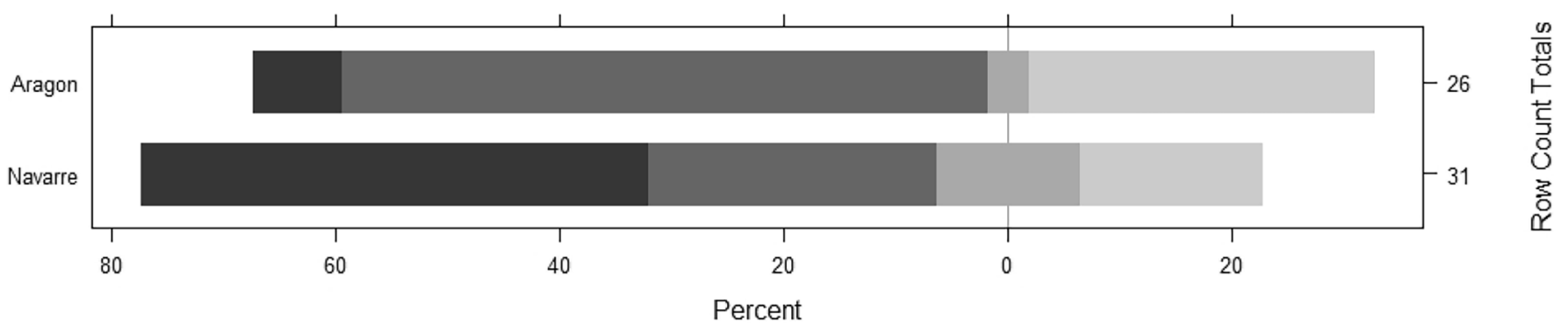

Strongly disagree $\square \quad$ Disagree $\square \quad$ Neither agree nor disagree $\square \quad$ Agree $\square \quad$ Strongly agree

Fig. 6 Distribution of responses on bear as an economic and environmental value of the area

disagreement (strongly disagree and disagree vs neither agree nor disagree, agree, strongly agree) increased 1.4 times in those farmers who took their sheep to summer ranges with bears.

Ninety-two percent of farmers $(n=53$, Table 1 Q7) considered that authorities did not report the bear situation in the Pyrenees properly.

\section{Other activities and presence of bear}

Bear presence was not perceived as an economic or environmental value (78\%, $n=57$; Table 1 Q6 and Fig. 5). The administrative region had a significant effect on the degree of agreement with the question (Fig. 6 and Table 2 Q6), multiplying the probability of disagreeing by 2.1 in farmers from Navarre. Seventy-one percent $(n=45)$ disagreed that the bear encouraged tourism activities in their area, and $79 \%(n=56)$ did not believe that it should be more used to promote this activity in the region (Fig. 6 and Table 1 Q18 and Q19). Forty-one percent $(n=37)$ considered bear as a disturbing factor for hunting practices, and $32 \%$ disagreed (Fig. 6 and Table 1 Q17).
Fifty-four percent $(n=43)$ believed that bears are a threat to people. The probability of disagreement was multiplied by 1.9 in farmers from Aragon (Fig. 7 and Table 2 Q16).

Fifty-eight percent of farmers $(n=45)$ did not consider poaching to be acceptable, although we observed how the response to this question varied between regions (Fig. 8 and Table 2 Q20), with the probability of disagreement about the acceptability of poaching being multiplied by 1.4 in Aragon, compared to Navarre.

\section{The importance of the existence of bears and their conservation}

Thirty-six percent of farmers $(n=56)$ did not consider important to have bears in Spain. This disagreement increased to $69 \%(n=58)$ if the item was referred to having bears in the Pyrenees, and reached $89 \%(n=56)$ if it was referring to their area (Fig. 9 and Table 1 Q8-Q10). The latter showed 1.4 times greater probability of disagreeing among those who took their sheep to summer ranges with bears, with respect to those grazing in areas without bears (Fig. 10 and Table 2 Q10). Similarly, 30\% of farmers $(n=55)$

\section{In this area bears are a threat to people}

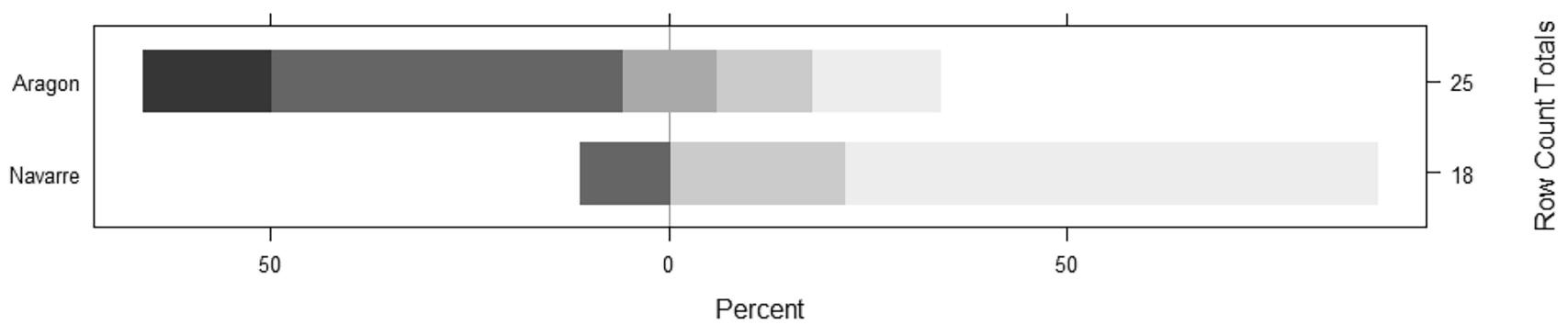

Strongly disagree $\square \quad$ Disagree $\square \quad$ Neither agree nor disagree $\square \quad$ Agree $\square \quad$ Strongly agree

Fig. 7 Distribution of responses on bear as a threat to people in their area 


\section{Bears poaching is acceptable}

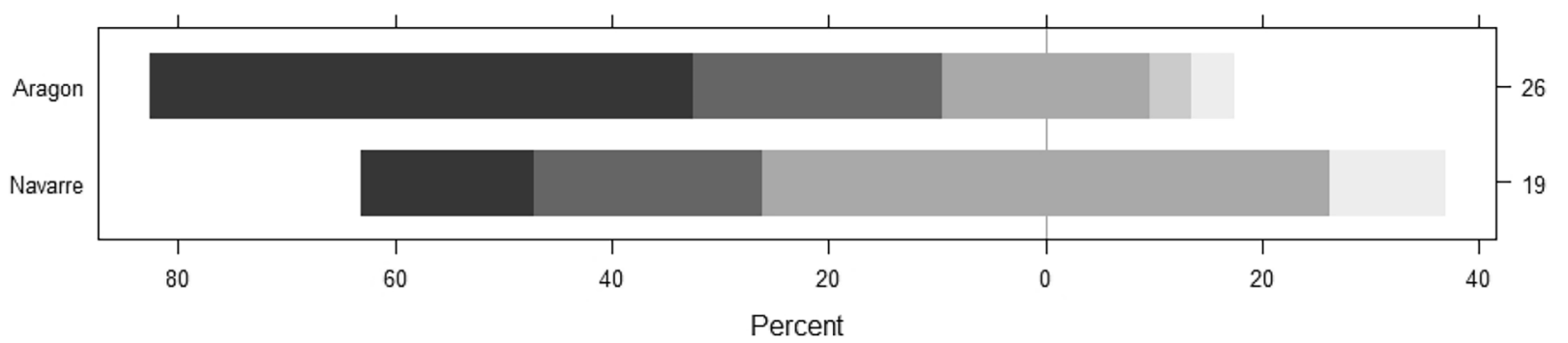

Fig. 8 Distribution of responses on the acceptance of bear poaching

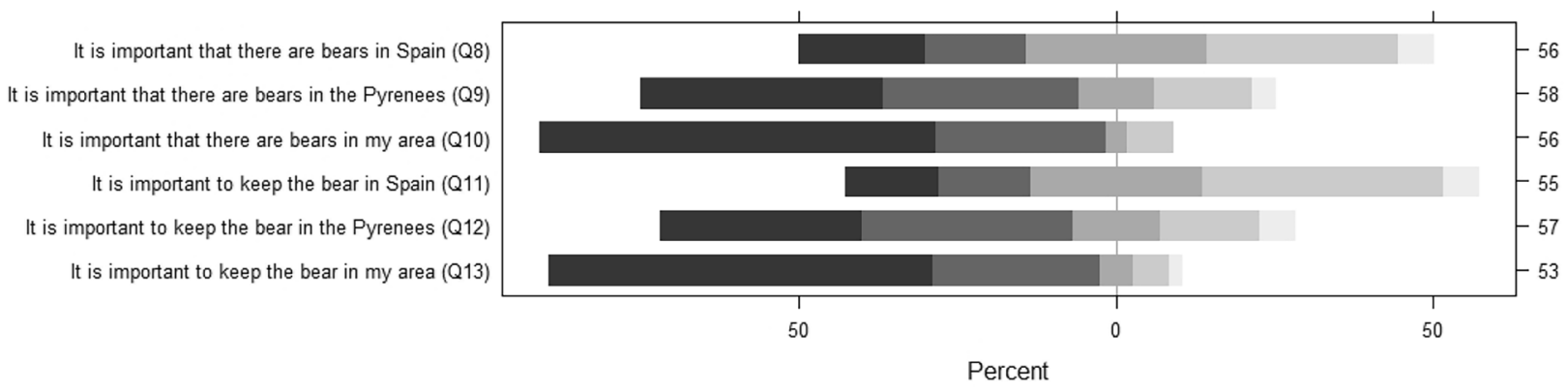

Fig. 9 Distribution of responses on the importance of having bears and their conservation

It is important that there are bears in my area

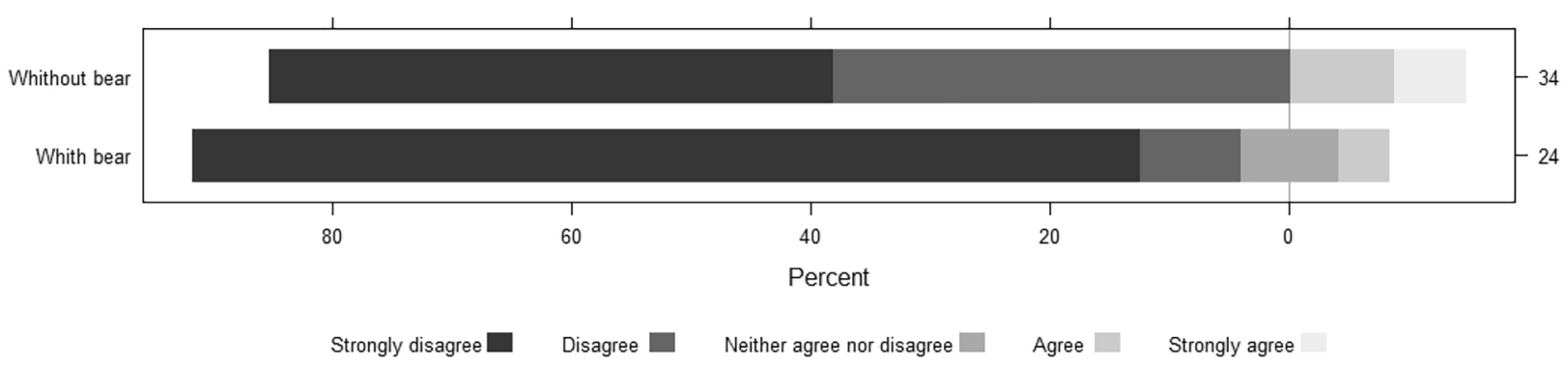

Fig. 10 Distribution of responses on the importance of having bears in their area

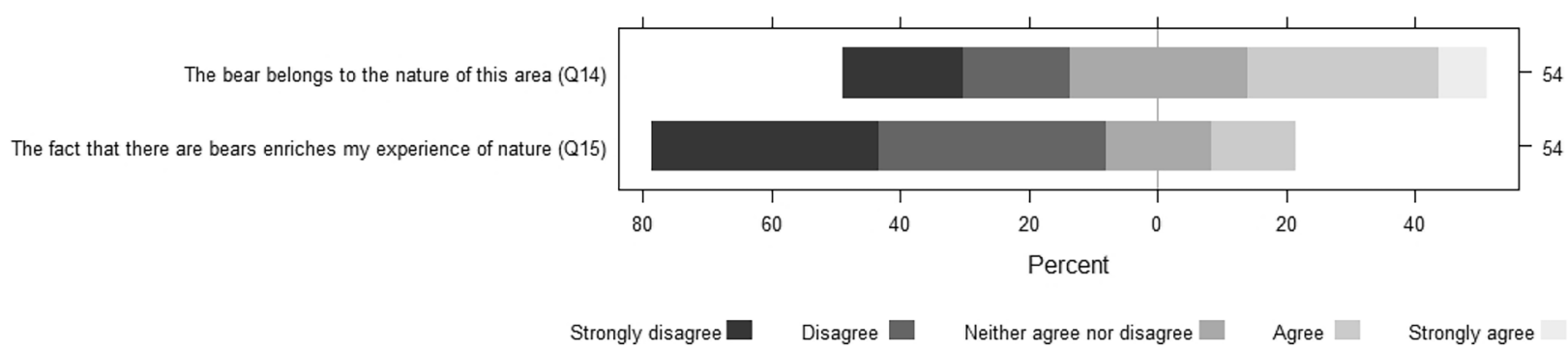

Fig. 11 Distribution of responses on bear and nature 
did not consider important to conserve bears in Spain, with this disagreement increasing to $65 \%(n=57)$ if the item was focused on the Pyrenees, and reaching $87 \%(n=53)$ if it was referred to their own area (Fig. 9 and Table 1 Q11-Q13).

Finally, $37 \%$ of farmers $(n=54)$ considered that bears belonged to the nature of their area (Fig. 11 and Table 1 Q14), and 70\% ( $n=54)$ disagreed with the fact that bears contribute to enrich their experience in nature (Fig. 11 and Table 1 Q15). Neither the region nor the use of mountain ranges with or without bears influenced the degree of agreement with these statements.

\section{Discussion}

The decline in the extensive sheep farming practice across the Pyrenees started in the middle of the XX century, and continuous nowadays (Roldán 2016). In many cases, large livestock (cows) (Fillat Estaqué et al. 2007) is replacing sheep farms, together with an increase in intensification of livestock practices (Navarro and López-Bao 2018). As reported by the most affected people, farmers, the main causes of this decline can be summarized in the following: a reduction of market profitability; lack of generational replacement, the difficulties to find shepherds due to current living standards, market fluctuation in terms of products and raw material values, and the insufficient EU agricultural policy subsidies, in spite of the subsidies devoted to sheep production. In a livestock sector in crisis, compensations for livestock damages alone will not prevent the decline of the activities (Berger 2006).

In this critical situation of the extensive sheep farming practices in these mountains, farmers consider the sporadic presence of bears as incompatible with mountain sheep grazing, even though they also reported that bears are not the main problem for the viability of the activity. Therefore, bears are playing here the role of scapegoat of other problems affecting livestock practices (Chapron and López-Bao

Table 1 Distribution of responses on knowledge, perceptions, and attitudes towards brown bears by Pyrenean sheep farmers. The numbering coincides with the order of appearance on the questionnaire

\begin{tabular}{|c|c|c|c|c|c|c|c|c|c|}
\hline & Question & $\begin{array}{l}\text { Strongly } \\
\text { disagree } \%\end{array}$ & Disagree \% & $\begin{array}{l}\text { Neither agree } \\
\text { nor disagree } \%\end{array}$ & Agree \% & $\begin{array}{l}\text { Strongly } \\
\text { agree } \%\end{array}$ & $n$ & $M$ score & $S D$ \\
\hline Q1 & $\begin{array}{l}\text { The presence of bear, currently, is compatible with } \\
\text { sheep farming }\end{array}$ & 56.9 & 17.3 & 1.7 & 15.5 & 8.6 & 58 & 1.02 & 1.42 \\
\hline Q2 & Your general attitude towards the bear is & 46.6 & 24.1 & 13.8 & 15.5 & 0.0 & 58 & 0.98 & 1.12 \\
\hline Q3 & $\begin{array}{l}\text { The main problem of extensive livestock is the } \\
\text { attacks caused by predators such as the bear }\end{array}$ & 9.3 & 61.1 & 7.4 & 16.7 & 5.5 & 54 & 1.48 & 1.06 \\
\hline Q4 & $\begin{array}{l}\text { The presence of bear is compatible with my livestock } \\
\text { activity }\end{array}$ & 63.8 & 17.2 & 13.8 & 3.5 & 1.7 & 58 & 0.62 & 0.97 \\
\hline Q5 & $\begin{array}{l}\text { The presence of bear is desirable with my livestock } \\
\text { activity }\end{array}$ & 78.6 & 14.3 & 7.1 & 0.0 & 0.0 & 56 & 0.29 & 0.59 \\
\hline Q6 & $\begin{array}{l}\text { The presence of bear increases the economic and } \\
\text { environmental value of the area }\end{array}$ & 28.1 & 40.3 & 8.8 & 22.8 & 0.0 & 57 & 1.26 & 1.11 \\
\hline Q7 & $\begin{array}{l}\text { The administration informs about the situation of the } \\
\text { bear in the Pyrenees }\end{array}$ & 69.8 & 22.6 & 5.7 & 0.0 & 1.9 & 53 & 0.42 & 0.77 \\
\hline Q8 & It is important that there are bears in Spain & 19.6 & 16.1 & 28.6 & 30.4 & 5.3 & 56 & 1.86 & 1.21 \\
\hline Q9 & It is important that there are bears in the Pyrenees & 37.9 & 31.0 & 12.1 & 15.5 & 3.5 & 58 & 1.16 & 1.2 \\
\hline Q10 & It is important that there are bears in my area & 62.5 & 26.8 & 3.6 & 7.1 & 0.0 & 56 & 0.55 & 0.87 \\
\hline Q11 & It is important to keep the bear in Spain & 14.6 & 14.5 & 27.3 & 38.2 & 5.4 & 55 & 2.05 & 1.16 \\
\hline Q12 & It is important to keep the bear in the Pyrenees & 31.6 & 33.3 & 14.0 & 15.8 & 5.3 & 57 & 1.30 & 1.22 \\
\hline Q13 & It is important to keep the bear in my area & 60.4 & 26.4 & 5.6 & 5.7 & 1.9 & 53 & 0.62 & 0.97 \\
\hline Q14 & The bear belongs to the nature of this area & 18.5 & 16.7 & 27.8 & 29.6 & 7.4 & 54 & 1.91 & 1.23 \\
\hline Q15 & $\begin{array}{l}\text { The fact that there are bears enriches my experience } \\
\text { of nature }\end{array}$ & 35.2 & 35.2 & 16.7 & 12.9 & 0.0 & 54 & 1.07 & 1.03 \\
\hline Q16 & In this area bears are a threat to people & 9.3 & 30.2 & 7.0 & 16.3 & 37.2 & 43 & 2.42 & 1.48 \\
\hline Q17 & $\begin{array}{l}\text { Bears are a significant annoyance to hunting in my } \\
\text { area }\end{array}$ & 2.7 & 29.7 & 27.1 & 21.6 & 18.9 & 37 & 2.24 & 1.16 \\
\hline Q18 & Bear encourage tourism in my area & 40.0 & 31.1 & 4.4 & 15.6 & 8.9 & 45 & 1.22 & 1.36 \\
\hline Q19 & $\begin{array}{l}\text { Bears would have to be more used to encourage } \\
\text { tourism in my area }\end{array}$ & 44.6 & 33.9 & 8.9 & 8.9 & 3.6 & 56 & 0.93 & 1.11 \\
\hline Q20 & Bears poaching is acceptable & 35.6 & 22.2 & 33.3 & 2.2 & 6.7 & 45 & 1.33 & 1.35 \\
\hline
\end{tabular}




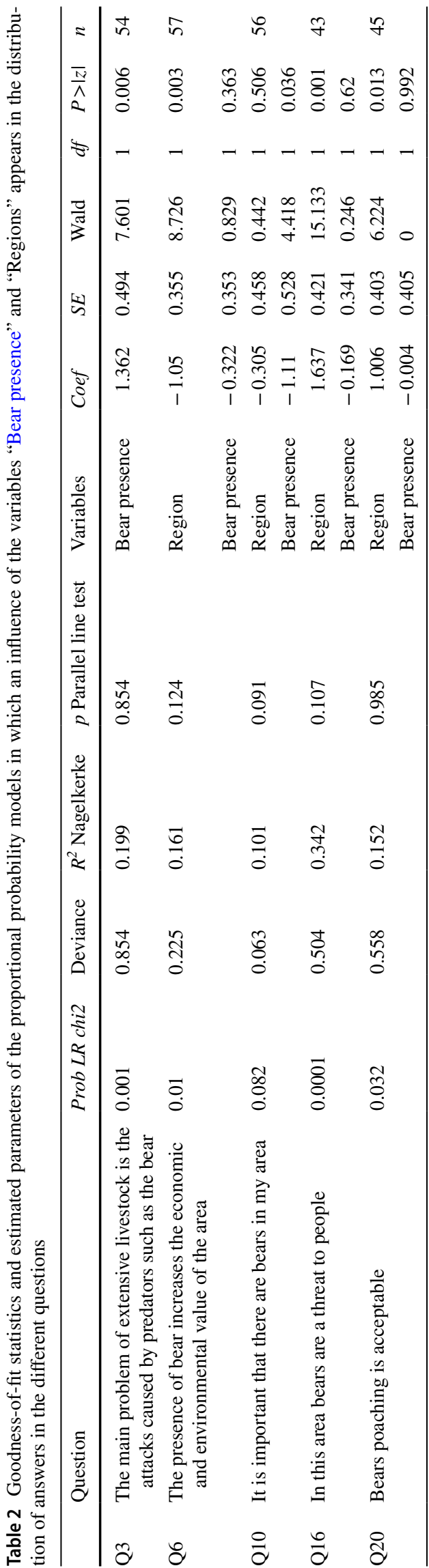

2014; Madden and MacQuinn 2014). Although it was not reported as the main problem for their activity, there was a negative attitude towards the presence of bears in the area, despite the fact one third of the farmers have suffered damages on their livestock. Attitude is worse when shepherds do not bring their flocks to summer pastures with brown bear presence. Therefore, it is important to focus on improving the acceptability, use, and effectiveness of bear damage prevention measures, which is expected to impact on the opposition to bears in the area (Eklund et al. 2017, 2020).

Importantly, some farmers already considered that they would be capable of changing their livestock husbandry practices in the presence of damages. We believe this result shows a willingness to co-adapt to the presence of bears, that it should be better exploited by authorities in delineating future actions to facilitate the coexistence between bears and humans in the area (Carter and Linnell 2016; López-Bao et al. 2017). In fact, some farmers were in favor of being proactive in the resolution of the human-bear conflict in the area, although others did not consider this possibility.

The vision of the Pyrenean sheepherders coincides with that of other similar studies on brown bear or other large carnivores and extensive sheep farming (Klenzendorf and Vaughan 1999). Interestingly, our results support the idea that the return of bears in areas where the species has almost disappeared, or has been absent for decades is perceived more negatively, perhaps associated with the loss of co-adaptation to coexist with this species (Carter and Linnell 2016; López-Bao et al. 2017). The attitudes and perceptions reported for the Western Pyrenees are more negative compared to other areas (Dressel et al. 2014), probably because the study focuses in a very specific interest group (extensive sheep farmers in remote mountainous areas), and the inquiries of European farmers do not specify their exact dedication in other studies (Dressel et al. 2014). Our results, indicate that, after few years in which there has been almost no presence of bears in the area, the management and dedication to herds in mountain pastures have adapted to this situation, changing the traditional ways of alleviating the damage of bear attacks, with several flocks being unguarded at present.

The preventive measures already undertaken in the area are insufficient at this moment. Some consider that extensive sheep grazing systems are not compatible with the existence of expanding brown bear populations (Sagør et al. 1997). Eventhough, there are a number of measures that have shown to be useful to reduce the damages of large carnivores in general (Eklund et al. 2017; van Eeden et al. 2018). Proposed measures include the use of fences (Ambarlı and Bilgin 2008; Foggin and Rabden 2010) or livestock guarding dogs (Andelt and Hopper 2000; Eklund et al. 2017; Gillin et al. 1997; Karamanlidis et al. 2011; Linnell and Lescureux 2015; Otstavel et al. 2009; Rigg 2004; Smith et al. 2000). However, still the use of these two 
measures should be generalized across farmers at the landscape scale and a greater focus should be placed in how to increase the effectiveness of these measures. Other damage prevention measures have proven to be also effective in other areas of the Pyrenees (change in herd management, based on measures such as pooling herds and hiring shepherds (Palazón et al. 2018). But it is important to evaluate the potential use in this area, as well as the acceptability of the different measures by the farmers (Eklund et al. 2020). We must underline the lack of knowledge of many farmers on subsidies for damage prevention.

Farmers perceive the compensations for damages by the administration in a clearly unsatisfactory way. These should provide economic aid for the maintenance of preventive measures, facilitate, and expedite economic compensations that take into account all direct damages (deaths, wounded animals, abortions) and indirect ones (increased surveillance, preparation of documents and parts). This may lead farmers to under-report damages. A clear request for improvement is to ask for an amount per dead sheep, plus a fixed price and a complementary aid. There is a need of a greater attention on the part of the administration, facilitating the maximum rapidity in the payments.

We conclude that farmers considered bear presence as incompatible with sheep mountain herding. One third of them have experienced bear damages, although this was not the main difficulty for the viability of farming practices. They were able to change husbandry practices after wildlife and dog's damages, increasing vigilance, hiring shepherds and using livestock guarding dogs, whose work is perceived as satisfactory. Farmers considered that information available about bear and compensation systems for damages was insufficient, and should be improved.

The results of bear monitoring, compensation, and damage prevention systems must be communicated to the farmers, hunters, and visitors. Besides, visitors should know on the presence of livestock guarding dogs and their consequent behavior in the mountain ranges. Longitudinal monitoring of the human dimensions in these interest groups is crucial in a context of bear recovery in order to detect factors that will deserve a greater attention along the bear recovery process in the Pyrenees.

Acknowledgements We would like to thank the willingness of the farmers to participate in the surveys.

Author contribution All the authors designed the interview. Ricardo Azón and Vicente Ferrer interviewed the farmers. Alicia García-Serrano performed the statistical analysis. Alicia García-Serrano, Juan Herrero, and Ramón Reiné wrote the draft. All the authors corrected the manuscript.

Funding Open Access funding provided thanks to the CRUE-CSIC agreement with Springer Nature. The Ministry of Ecological Transition of Spain provided funds. JVLB was supported by a Ramón \& Cajal research contract (RYC-2015-18932) from the Spanish Ministry of
Economy, Industry and Competitiveness and the Project CGL201787528-R AEI/FEDER EU.

Data availability The datasets generated are available from the corresponding author on reasonable request.

Code availability Z125-3301-14 (international program license agreement) IBM SPSS Statistical version 26.

\section{Declarations}

Ethics approval Informed consent was obtained from all individual participants included in the study by the authors before conducting the surveys, and all respondent information has been protected to ensure that human rights were not infringed.

Consent to participate All authors have approved to participate in this publication.

Consent for publication All authors have approved to publish these results.

Conflict of interest The authors declare no competing interests.

Open Access This article is licensed under a Creative Commons Attribution 4.0 International License, which permits use, sharing, adaptation, distribution and reproduction in any medium or format, as long as you give appropriate credit to the original author(s) and the source, provide a link to the Creative Commons licence, and indicate if changes were made. The images or other third party material in this article are included in the article's Creative Commons licence, unless indicated otherwise in a credit line to the material. If material is not included in the article's Creative Commons licence and your intended use is not permitted by statutory regulation or exceeds the permitted use, you will need to obtain permission directly from the copyright holder. To view a copy of this licence, visit http://creativecommons.org/licenses/by/4.0/.

\section{References}

AA. VV. (2009) Bases ecológicas preliminares para la conservación de los tipos de hábitat de interés comunitario en España. Ministerio de Medio Ambiente, y Medio Rural y Marino

Ambarlı H, Bilgin CC (2008) Human-brown bear conflicts in Artvin, Northeastern Turkey: encounters, damage, and attitudes. Ursus 19(2):146-153. https://doi.org/10.2192/1537-6176-19.2.146

Andelt WF, Hopper SN (2000) Livestock guard dogs reduce predation on domestic sheep in Colorado. J Range Manag 53:259-267

Bautista C, Naves J, Revilla E, Fernández N, Albrecht J, Scharf AK, Rigg R, Karamanlidis AA, Jerina K, Huber Đ (2017) Patterns and correlates of claims for brown bear damage on a continental scale. J Appl Ecol 54(1):282-292

Berger KM (2006) Carnivore-livestock conflicts: effects of subsidized predator control and economic correlates on the sheep industry. Conserv Biol 20(3):751-761. https://doi.org/10.1111/j.1523-1739. 2006.00336.x

Bombieri G, Delgado MDM, Russo LF et al (2018) Patterns of wild carnivore attacks on humans in urban areas. Sci Rep 8:7728. https://doi.org/10.1038/s41598-018-36034-7

Carter NH, Linnell JDC (2016) Co-adaptation is key to coexisting with large carnivores. Trends Ecol Evol 31(8):575-578. https://doi.org/ 10.1016/j.tree.2016.05.006 
Caussimont G, Herrero J (1997) The brown bear in the Spanish Pyrenees: present status and recommendations for protection. Int Conf Bear Res and Manage 9(2):7-12

Chapron G, Kaczensky P, Linnell JDC et al (2014) Recovery of large carnivores in Europe's modern human-dominated landscapes. Science 346(6216):1517-1519. https://doi.org/10.1126/science. 1257553

Chapron G, López-Bao JV (2014) Conserving carnivores: politics in play. Science 343(6176):1199-1200

Chapron G, López-Bao JV (2016) Coexistence with large carnivores informed by community ecology. Trends Ecol Evol 31(8):578-580

Dressel S, Sandström C, Ericsson G (2014) A meta-analysis of studies on attitudes toward bears and wolves across Europe 1976-2012: meta-analysis of studies on attitudes toward bears and wolves. Conserv Biol 29(2):565-574. https://doi.org/10.1111/cobi.12420

Eklund A, Johansson M, Flykt A et al (2020). Believed effect-a prerequisite but not a guarantee for acceptance of carnivore management interventions. Biol Conservation 241:108251

Eklund A, López-Bao JV, Tourani M, Chapron G, Frank J (2017) Limited evidence on the effectiveness of interventions to reduce livestock predation by large carnivores. Sci Rep 7(2097):1-9. https:// doi.org/10.1038/s41598-017-02323-w

Ferrer V, Canals RM (2011) Proyecto de Ordenación de los recursos pascícolas forestales del Valle de Roncal. Dto. de Medio Ambiente y Desarrollo Rural. Gobierno de Navarra

Fillat Estaqué F, García-González R, Gómez-García D, Reiné Viñuales R (2007) Pastos del Pirineo. Consejo Superior de Investigaciones Científicas

Foggin MJ, Rabden J (2010) Trial use of electric fencing to prevent intrusions by Tibetan brown bear. International Bear News 19(1):15-18

Gastón Romeo MG, de la Riva FJ (2015) Análisis espacial y representación geográfica innovación y aplicación. In: de la Riva J, Ibarra P, Montorio R, Rodrigues M (eds) Análisis espacial y representación geográfica: Innovación y aplicación. Universidad de Zaragoza-AGE, pp 641-650

Gillin CM, Chestin I, Semchenkov P, Claar J (1997) Management of bear-human conflicts using Laika dogs. Int Conf Bear Res and Manage 9(2):133-137

Glikman JA, Ciucci P, Marino A et al (2019) Local attitudes toward Apennine brown bears: insights for conservation issues. Conservation Science and Practice 1(5):e25. https://doi.org/10.1111/csp2.25

Heiberger RM (2020) HH: statistical analysis and data display: Heiberger and Holland (Versión R package version 3.1-40) [Computer software]. https://CRAN.R-project.org/package $=\mathrm{HH}$

Heiberger RM, Robbins NB (2014) Design of diverging stacked bar charts for Likert scales and other applications. Journal of Statistical Software, 57(5), 1-32. https://doi.org/10.18637/jss.v057.i05

Hovardas T (2018) Large carnivore conservation and management: human dimensions. Routledge

Johansson M, Sjöström M, Karlsson J, Brännlund R (2012) Is human fear affecting public willingness to pay for the management and conservation of large carnivores? Soc Nat Resour 25(6):610-620

Kansky R, Knight AT (2014) Key factors driving attitudes towards large mammals in conflict with humans. Biol Cons 179:93-105

Karamanlidis AA, Sanopoulos A, Georgiadis L, Zedrosser A (2011) Structural and economic aspects of human-bear conflicts in Greece. Ursus 22(2):141-151. https://doi.org/10.2192/ URSUS-D-10-00016.1

Klenzendorf S, Vaughan MR (1999) An overview of brown bear managemnet in six european countries. Ursus 11:163-178

Likert R (1932) A technique for the measurement of attitudes. Archives of Psychology 22:5-55

Linnell JDC, Lescureux N (2015) Livestock guarding dogs. Cultural heritage icons with a new relevance for mitigating conservation conflicts (Norwegian Institute for Nature Research)
López-Bao JV, Bruskotter J, Chapron G (2017) Finding space for large carnivores. Nature Ecology \& Evolution 1(0140):1-2. https://doi.org/10.1038/s41559-017-0140

Madden F, McQuinn B (2014) Conservation's blind spot: the case for conflict transformation in wildlife conservation. Biol Cons 178:97-106

Madoz P (1846) Diccionario geográfico-estadístico-histórico de España y sus posesiones de ultramar (Vol. 4). Est. tip. de P. Madoz and L. Sagasti

Majić A, Taussig M, de Bodonia A, Huber Đ, Bunnefeld N (2011) Dynamics of public attitudes toward bears and the role of bear hunting in Croatia. Biol Cons 144(12):3018-3027. https://doi.org/ 10.1016/j.biocon.2011.09.005

Mangado JM (2016) Evolución de los pastos y la ganadería extensiva en Navarra: Propuestas para controlar su descenso. Navarra Agraria 215:23-30

MAPA, Ministerio de Agricultura, Pesca y Alimentación (2019). Catálogo oficial de razas. Ovino. https://www.mapa.gob.es/es/ ganaderia/temas/zootecnia/razas-ganaderas/razas/catalogo-razas/

Navarro A, López-Bao JV (2018) Towards a greener common agricultural policy. Nature Ecology \& Evolution 2(12):1830-1833

Naves J, Ordiz A, Fernández-Gil A et al (2018) Patterns of brown bear damages on apiaries and management recommendations in the Cantabrian Mountains, Spain. PloS one 13(11)

Otstavel T, Vuori KA, David DE et al (2009) The first experience of livestock guarding dogs preventing large carnivore damages in Finland. Estonian Journal of Ecology 58(3):216. https://doi.org/ 10.3176/eco.2009.3.06

Palazón S, Afonso I, Batet A et al (2018) Bear attacks and damages on livestock and apiculture in Catalonia: are effective the protection measures?. 26th International Conf on Bear Res Management 1

Palazón S, Ruiz-Olmo J, Trias B et al (2013) La población de osos de los Pirineos sube poco a poco. Quercus 327:31-33

Palazón S (2017) The importance of reintroducing large carnivores: the brown bear in the Pyrenees. En J. Catalan, J. M. Ninot, \& M. M. Aniz (Eds.), High Mountain Conservation in a Changing World (Vol. 62, pp. 231-249). Springer International Publishing. https:// doi.org/10.1007/978-3-319-55982-7

Piédallu B, Quenette PY, Jordana IA et al (2016a) Better together: a transboundary approach to brown bear monitoring in the Pyrenees. bioRxiv 075663

Piédallu B, Quenette PY, Mounet C et al (2016b) Spatial variation in public attitudes towards brown bears in the French Pyrenees. Biol Cons 197:90-97

Piédallu B, Quenette P-Y, Bombillon, et al (2019) Determinants and patterns of habitat use by the brown bear Ursus arctos in the French Pyrenees revealed by occupancy modelling. Oryx 53(2):334-343. https://doi.org/10.1017/S0030605317000321

Planella A, Jiménez J, Palomero G et al (2019) Integrating critical periods for bear cub survival into temporal regulations of human activities. Biol Cons 236:489-495. https://doi.org/10.1016/j.biocon.2019.05.051

Rigg R (2004) The extent of predation on livestock by large carnivores in Slovakia and mitigating carnivore-human conflict using livestock guarding dogs. [Degree of MSc]. University of Aberdeen

Roldán L (2016) El ovino y el caprino en Aragón. Evolución en los 20 últimos años (1996-2016) (p. 23). Gobierno de Aragón

Sagør JT, Swenson JE, Røskaft E (1997) Compatibility of brown bear Ursus arctos and free-ranging sheep in Norway. Biol Cons 81(12):91-95. https://doi.org/10.1016/S0006-3207(96)00165-6

Sakurai R, Tsunoda H, Enari H et al (2020) Factors affecting attitudes toward reintroduction of wolves in Japan. Global Ecology and Conservation 22:e01036. https://doi.org/10.1016/j.gecco.2020. e01036 
Smith ME, Linnell JD, Odden J, Swenson JE (2000) Review of methods to reduce livestock depredation: I. Guardian Animals Acta Agriculturae Scandinavica 50:279-289

Treves A, Bruskotter J (2014) Tolerance for predatory wildlife. Science 34:476-477

Urzainki A (1980) Evolución de la ganadería en el valle del Roncal. Lurralde 3:43-100

van Eeden LM, Eklund A, Miller JRB et al (2018) Carnivore conservation needs evidence-based livestock protection. PLoS Biol 16(9):e2005577. https://doi.org/10.1371/journal.pbio.2005577
Villar L, Lorda M (1992) El sistema ganadero roncalés en los últimos quince años: Evolución y perspectivas. XXXII Reunión Científica de la SEEP 378-384

Williams CK, Ericsson G, Heberlein TA (2002) A quantitative summary of attitudes toward wolves and their reintroduction (19722000). Wildl Soc Bull 30(2):1-10

Publisher's Note Springer Nature remains neutral with regard to jurisdictional claims in published maps and institutional affiliations. 